\title{
Preparation and first biological evaluation of novel Re-188/Tc-99m peptide conjugates with substance-P
}

\author{
Katarina Smilkov ${ }^{\mathrm{a}}$, Emilija Janevik ${ }^{\mathrm{a}}$, Remo Guerrini ${ }^{\mathrm{b}}$, Micol Pasquali ${ }^{\mathrm{c}}$, Alessandra Boschi ${ }^{\mathrm{c}}$, \\ Licia Uccelli ${ }^{c}$, Giovanni Di Domenico ${ }^{\mathrm{a}, \mathrm{b}, \mathrm{c}}$, Adriano Duatti ${ }^{\mathrm{c} * *}$ \\ a Faculty of Medical Sciences, University 'Goce Delcev', Stip, Macedonia \\ b Department of Chemical and Pharmaceutical Sciences, University of Ferrara, 44121 Ferrara, Italy \\ c Laboratory of Nuclear Medicine, Department of Experimental Medicine, University of Ferrara, Via L. Borsari, 46, 44121 Ferrara, Italy
}

\section{H I G H L I G H T S}

- First application of a novel approach for labeling peptides to the preparation of Tc-99m and Re-188 with substance-P.

- Characterization of new, structurally identical radioconjugates of substance-P with Tc-99m and Re-188.

- Preliminary biological evaluation of the new Tc-99m and Re-188 peptide radioconjugates.

\section{A R T I C L E I N F O}

\section{Article history:}

Received 22 January 2014

Received in revised form

13 April 2014

Accepted 2 June 2014

Available online 12 June 2014

Keywords:

Technetium-99m

Rhenium-188

Substance-P

Peptide radiopharmaceuticals

Metal nitrido radiopharmaceuticals
G $R$ A P H I C A L A B S T R A C T

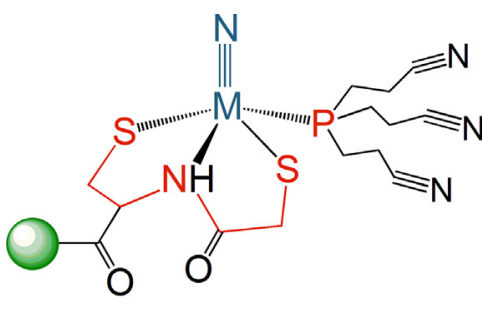

$M=$ Tc-99m, Re-188; $Q=$ Substance $P$

\begin{abstract}
A B S T R A C T
Introduction: New ${ }^{188} \mathrm{Re}$ and ${ }^{99 \mathrm{~m}} \mathrm{Tc}$ peptide conjugates with substance- P (SP) were prepared and biologically evaluated. The radiopharmaceuticals have been labelled with the $[\mathrm{M} \equiv \mathrm{N}]^{2+}\left(\mathrm{M}={ }^{99 \mathrm{~m}} \mathrm{Tc}\right.$, ${ }^{188} \mathrm{Re}$ ) core using a combination of $\pi$-donor tridentate and $\pi$-acceptor monodentate ancillary ligands. Methods: The new radiopharmaceuticals have been prepared through a two-step reaction by simultaneous addition of the tridentate and monodentate ligands to a vial containing a preformed $[\mathrm{M} \equiv \mathrm{N}]^{2+}$ core. The tridentate ligand was formed by linking two cysteine residues to the terminal arginine of the undecapeptide SP, whereas the monodentate ligand was a tertiary phosphine. The preparation of the corresponding Re-188 derivative required developing a more complex chemical procedure to obtain the $[\mathrm{Re} \equiv \mathrm{N}]^{2+}$ core in satisfactory yields. Characterization of the resulting products was obtained by chromatographic methods. Biological evaluation was performed for both Tc-99m and Re-188 derivatives by in-vitro studies on isolated cells expressing NK1-receptors. In-vivo imaging in mice was carried out using a small-animal YAP(S)PET tomograph.

Conclusion: New Tc-99m and Re-188 peptide radiopharmaceuticals with SP have been prepared in highyield and with high-specific activity. Both Tc-99m and Re-188 peptide radioconjugates exhibit high affinity for NK1 receptors, thus giving further evidence to the empirical rule that structurally related Tc-99m and Re-188 radiopharmaceuticals exhibit identical biological properties.
\end{abstract}

(c) 2014 Elsevier Ltd. All rights reserved.

\footnotetext{
* Corresponding author.

E-mail address: adriano.duatti@unife.it (A. Duatti).
}

\section{Introduction}

Technetium-99m is still the most widely used diagnostic radionuclide owing to its almost ideal nuclear properties $\left(E_{\gamma}=140 \mathrm{keV}\right.$, $t_{1 / 2}=6.06 \mathrm{~h}$ ) and easy availability through the transportable 
Mo-99/Tc-99m generator. Similarly, rhenium-188 was early recognized as one of the most attractive radionuclide for therapy as it decays through the emission of a high-energy $\beta$-particle $\left(E_{\beta \max }=2.1 \mathrm{MeV}, t_{1 / 2}=16.9 \mathrm{~h}\right)$ with an associated $\gamma$-emission (155 keV) that can be conveniently utilized for imaging purposes (Ferro-Flores and Arteaga de Murphy, 2008). This radionuclide is also produced, in very high specific activity and radionuclidic purity, through the transportable ${ }^{188} \mathrm{~W} /{ }^{188}$ Re generator system (Pillai et al., 2012). These two transition elements share a similar chemistry, which allows obtaining analogous complexes having the same structural characteristics with many categories of ligands though this does not occur ubiquitously for all types of compounds (Bhattacharyya and Dixit, 2011). However, a key result that has been firmly demonstrated experimentally maintains that, when a pair of ${ }^{99 \mathrm{~m}} \mathrm{Tc}$ and ${ }^{188} \mathrm{Re}$ complexes exhibit exactly the same molecular structure and chemical composition, but differ only for the metal ion, they exhibit the same biodistribution properties (Duatti, 2011). Thus, these two structurally identical complexes constitutes a true theranostic (diagnostic + therapeutic) pair and not simply a surrogate pair like ${ }^{111} \mathrm{In} /{ }^{90} \mathrm{Y}$ and $\left.{ }^{68} \mathrm{Ga} /{ }^{177} \mathrm{Lu}\right] \mathrm{com}-$ plexes (Kelkar and Reineke, 2011; Price and Orvig, 2014). This result can be conveniently exploited to facilitate the development of structurally identical ${ }^{188} \mathrm{Re}$ therapeutic agents through the preliminary investigation of the pharmacokinetic and pharmacodynamics properties of the corresponding ${ }^{99 \mathrm{~m}} \mathrm{Tc}$ complexes (Park and Kim, 2013).

Recently, we described a new chelating arrangement for developing theranostic pairs of ${ }^{99 \mathrm{~m}} \mathrm{Tc}$ and ${ }^{188} \mathrm{Re}$ radiopharmaceuticals. This molecular fragment is composed by a combination of tridentate and monodentate ligands bound to a $[\mathrm{M} \equiv \mathrm{N}]^{2+}$ $\left(\mathrm{M}={ }^{99 \mathrm{~m}} \mathrm{Tc},{ }^{188} \mathrm{Re}\right)$ group as schematically pictured in Fig. 1 (Boschi et al., 2013). The $[\mathrm{M} \equiv \mathrm{N}]^{2+}\left(\mathrm{M}={ }^{99 \mathrm{~m}} \mathrm{Tc},{ }^{188} \mathrm{Re}\right)$ inorganic functional group exhibits an elegant and predictable chemistry sharply controlled by the chemical nature of the coordinating ligands. In this specific example, the tridentate ligand binds the metallic fragment through a set of three $\pi$-donor atoms whereas the monodentate ligand through a single $\pi$-acceptor atom (Boschi et al., 2012). The resulting mixed complexes form exclusively when these two type of ligands are simultaneously added to the intermediate $[\mathrm{M} \equiv \mathrm{N}]^{2+}$ fragment, thus indicating that this molecular arrangement are endowed with high structural stability. A significant advantage of this approach is that suitable tridentate chelating systems can be conveniently formed by joining pair of aminoacids or pseudo-aminoacids such as, for example, cysteinecysteine, cysteine-isocysteine or cysteine-mercaptoacetic acid (Boschi et al., 2013). This result may provide an almost 'natural' and straightforward method for labeling peptides with Tc-99m and Re-188 since it only requires lengthening the original peptidic sequence with a pair of these chelating aminoacids.

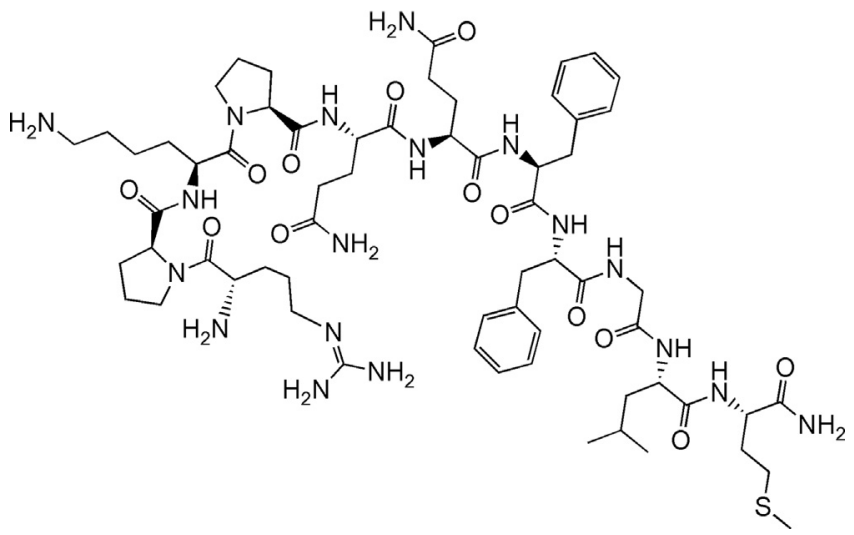

Fig. 1. Drawing of the chemical structure of substance-P (SP).
The present work was mostly devoted to investigate the application of the new labeling approach with Tc-99m and Re188 to a model peptide. The undecapeptide substance-P (SP) was selected for this purpose. SP is the most important member of the tachykinin family that constitutes the major endogenous ligand for the NK1 receptor type. Tachykinins are excitatory neuropeptides synthesised in neuronal and glial cells of the human central and peripheral nervous system. These peptides act as excitatory neurotransmitters and/or neuromodulators and induce DNA synthesis leading to stimulation of cell division and proliferation. Their biological responses are triggered via the well-established tachykinin receptors NK1, NK2 and NK3 that belong to the G protein-coupled receptor family (GPCRs). It has been well established that SP plays an important role in modulating pain transmission and may be also involved in the pathogenesis of inflammatory diseases (Van Hagen et al., 2005). The presence of functional NK1 receptors has been documented in malignant brain tumors of glial origin, medullary thyroid cancer, non-small cell lung cancer and pancreatic carcinoma. It has been suggested that targeting specific SP-NK1 receptors might provide a potential strategy for developing both new tumor-specific diagnostic agents and radionuclide-based anti-cancer therapy (Ansquer et al., 2009).

In the following, the preparation and characterization of novel Tc-99m and Re-188 radiopharmaceuticals containing a 'naturally' modified SP peptide sequence are described. A preliminary biological evaluation of the resulting radiolabeled conjugates is also reported.

\section{Materials and methods}

\subsection{General}

Unless stated otherwise, chemicals were obtained from commercial sources and used without further purification. Protected amino acids, resins and reagents for the solid phase peptide synthesis were purchased form Novabiochem (Laufelfingen, Switzerland) or Anaspec (Campus Drive, Fremont, CA, USA).

Succinic dihydrazide $\left[\mathrm{SDH}=\mathrm{H}_{2} \mathrm{~N}-\mathrm{NH}-(\mathrm{O}=) \mathrm{C}-\left(\mathrm{CH}_{2}\right)_{2}-\mathrm{C}(=\mathrm{O})-\mathrm{NH}-\right.$ $\mathrm{NH}_{2}$ ], $\gamma$-hydroxypropylcyclodextrin, 1,2-diaminopropane- $N, N, N^{\prime} N^{\prime}$-tetraacetic acid, sodium dihydrogen phosphate monohydrate $\left(\mathrm{NaH}_{2}-\right.$ $\left.\mathrm{PO}_{4} \cdot \mathrm{H}_{2} \mathrm{O}\right)$, disodium hydrogen phosphate heptahydrate $\left(\mathrm{Na}_{2} \mathrm{HPO}_{4}\right.$. $\left.7 \mathrm{H}_{2} \mathrm{O}\right)$ the sodium salt of oxalic acid $\left(\mathrm{Na}_{2} \mathrm{C}_{2} \mathrm{O}_{4}\right), \mathrm{SnCl}_{2} \cdot 2 \mathrm{H}_{2} \mathrm{O}$, ascorbic acid, tris(2-cyanoethyl)phosphine [ $\left.\mathrm{PCN}=\mathrm{P}\left(\mathrm{CH}_{2} \mathrm{CH}_{2} \mathrm{CN}\right)_{3}\right]$, trifluoroacetic acid (TFA), L-cysteine and glutathione (GSH) were obtained from Aldrich. Polyethyleneglycol-600 diacid $\left(\mathrm{HO}_{2} \mathrm{C}-\mathrm{PEG}_{600}-\mathrm{CO}_{2} \mathrm{H}\right)$ was purchased from Sigma-Aldrich. The compound methyl 2-(3,4-dichlorobenzoyl)-1-methylhydrazinecarbodithioate $\left[\mathrm{Cl}_{2} \mathrm{C}_{6} \mathrm{H}_{3} \mathrm{C}(=\mathrm{O}) \mathrm{NH}-\mathrm{N}\left(\mathrm{CH}_{3}\right)\right.$ $\left.\mathrm{SCH}_{3}=\mathrm{MDTCZ}\right]$ and butyl 2-(3,4-dichlorobenzoyl)-1-methylhydrazinecarbodithioate $\left[\mathrm{Cl}_{2} \mathrm{C}_{6} \mathrm{H}_{3} \mathrm{C}(=\mathrm{O}) \mathrm{NH}-\mathrm{N}\left(\mathrm{CH}_{3}\right) \mathrm{SC}_{4} \mathrm{H}_{9}=\mathrm{BDTCZ}\right]$, were prepared according to literature procedures (Szczesio et al., 2012).

Rhenium-188, as carrier free $\left[{ }^{188} \mathrm{ReO}_{4}\right] \mathrm{Na}$ in physiological solution, was obtained by elution from a ${ }^{188} \mathrm{~W} /{ }^{188}$ Re generator provided by Polatom (Poland). To obtain high volumic activity, the generator was equipped with a concentration system assembled as described elsewhere (Guhlke et al., 2000). Technetium-99m, as [ $\left.{ }^{99 m} \mathrm{TcO}_{4}\right] \mathrm{Na}$ in physiological solution, was obtained from a ${ }^{99 \mathrm{~m}} \mathrm{Mo} /{ }^{99 \mathrm{~m}} \mathrm{Tc}$ generator Elumatic ${ }^{\mathbb{R}}$ III (CisBio/IBA Molecular, France).

\subsection{Peptide synthesis and purification}

The aminoacidic sequence of the undecapeptide substance-P was prolonged by addition of two sequential cysteine residues to N-terminal to afford the bifunctional ligand Cys-Cys-Arg-Pro-LysPro-Gln-Gln-Phe-Phe-Gly-Leu-Met-NH $\mathrm{NH}_{2}$ (Cys-Cys-SP). In Figs. 1 and 2, drawings of the chemical structures of SP and Cys-Cys-SP are 


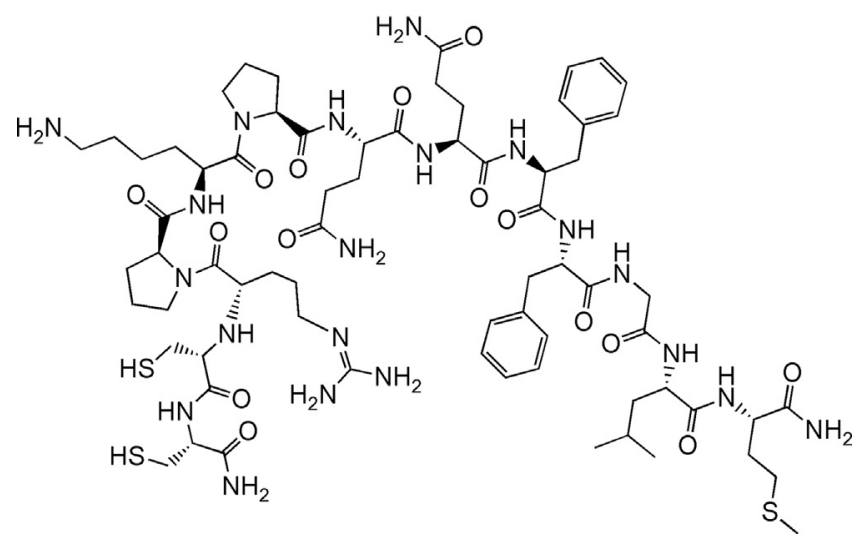

Fig. 2. Drawing of the chemical structure of Cys-Cys-substance-P (Cys-Cys-SP).

reported, respectively. Peptides were synthesized with an automatic solid phase peptide synthesizer Syro II (Biotage, Uppsala, Sweden) using Fmoc/tBu chemistry (Benoiton, 2005). The resin 4-(2',4'dimethoxyphenyl-Fmoc-aminomethyl)-phenoxyacetamido-norleucyl-MBHA (Rink amide MBHA resin) was used as a solid support. The resin was treated with $40 \%$ piperine/ $N, N$-dimethylformamide (DMF) and linked with Fmoc-Met-OH by using O-(7-azabenzotriazol-1-yl)1,1,3,3-tetramethyluronium hexafluorophosphate (HATU) as coupling reagent. For the synthesis of Cys-Cys-SP, the following $N^{-}$-Fmoc amino acids were sequentially coupled to the growing peptide chain: Fmoc-Leu-OH, Fmoc-Gly-OH, Fmoc-Phe-OH, Fmoc-Phe-OH, Fmoc-Gln (Trt)-OH, Fmoc-Gln(Trt)-OH, Fmoc-Pro-OH, Fmoc-Lys(Boc)-OH, FmocPro-OH, Fmoc-Arg(Pmc)-OH, Fmoc-Cys(Trt)-OH and Fmoc-Cys(Trt)$\mathrm{OH}$. All the Fmoc amino acids (4 equiv) were coupled to the growing peptide chain by using HATU (4 equiv) in DMF in the presence of an equimolar concentration of 4-methylmorpholine (NMM), and the coupling reaction was carried out for $1 \mathrm{~h}$. To improve the analytical profile of the crude peptide, capping with acetic anhydride $(0.5 \mathrm{M}$ in DMF) in the presence of NMM (0.25 M in DMF) (3:1, v/v; $2 \mathrm{~mL} / 0.2 \mathrm{~g}$ of resin) was performed at any step with the only exception of the last coupling. The mixture $40 \%$ piperidine/DMF was used to remove the Fmoc group at every step. The peptide resin was washed with methanol and dried in vacuo to yield the protected SP-Resin derivatives. The protected peptide-resin was treated with reagent B (Solé and Barany, 1992) (trifluoroacetic acid (TFA)/ $\mathrm{H}_{2} \mathrm{O} /$ phenol/triisopropylsilane $(88: 5: 5: 2 \mathrm{v} / \mathrm{v} ; 10 \mathrm{~mL} / 0.2 \mathrm{~g}$ of resin) for $1.5 \mathrm{~h}$ at room temperature. After filtration of the resin, the solvent was concentrated in vacuo and the residue triturated with ether. The crude peptide was purified by preparative reverse phase HPLC to yield a white powder after lyophilisation.

Crude peptides were purified by preparative reversed-phase HPLC using a Water Delta Prep 3000 system with a Jupiter column $\mathrm{C}_{18}(250 \times 30 \mathrm{~mm}, 300 \mathrm{~A}, 15 \mu \mathrm{m}$ spherical particle size $)$. The column was perfused at a flow rate of $20 \mathrm{~mL} / \mathrm{min}$ with a mobile phase containing solvent $A(5 \%, v / v$, acetonitrile in $0.1 \%$ TFA), and a linear gradient from 0 to $70 \%$ of solvent B $(60 \%, v / v$, acetonitrile in $0.1 \%$ TFA) over 25 min for the elution of peptides. Analytical HPLC analyses were performed on a Beckman 116 liquid chromatograph equipped with a Beckman 166 diode array detector. Analytical purity of the peptides were determined using a Luna $C_{18}$ column $(4.6 \times 100 \mathrm{~mm}, 3 \mu \mathrm{m}$ particle size) with the above solvent system (solvents A and B) programmed at a flow rate of $0.5 \mathrm{~mL} / \mathrm{min}$ using a linear gradient from $0 \%$ to $80 \%$ B over 25 min. Purity of the final peptide was $\geq 95 \%$ when monitored at $220 \mathrm{~nm}$.

\subsection{Preparation of Tc-99m and Re-188 peptide radioconjugates}

Freshly generator-eluted $\mathrm{Na}\left[{ }^{99 \mathrm{~m}} \mathrm{TcO}_{4}\right](0.9 \mathrm{~mL}, \sim 500 \mathrm{MBq})$ was added to a nitrogen-purged vial containing $1.0 \mathrm{mg}$ of solid SDH,
$0.10 \mathrm{mg}$ of $\mathrm{SnCl}_{2}$ and $0.10 \mathrm{~mL}$ of saline. The mixture was gently swirled to ensure dissolution of the reagents and kept at room temperature for $15 \mathrm{~min}$ to yield the $\left[{ }^{99 \mathrm{~m}} \mathrm{Tc} \equiv \mathrm{N}\right]^{2+}$ group. A solution of Cys-Cys-SP, obtained by dissolving an amount of the peptide ligand (in the range $0.5-0.05 \mathrm{mg}$ ) in $0.5 \mathrm{~mL}$ of saline, and another solution, obtained by dissolving $0.5 \mathrm{mg}$ of PCN and $2.0 \mathrm{mg}$ of $\gamma$-hydroxypropylcyclodextrin in $0.5 \mathrm{~mL}$ of saline, were freshly prepared and then simultaneously added to the reaction vial containing the radioactive Tc-99m nitrido intermediate. The vial was heated at $100{ }^{\circ} \mathrm{C}$ for $30 \mathrm{~min}$. The radiochemical yield, as determined by HPLC chromatography (see below), ranged from 92 to $96 \%$ by increasing the concentration of the peptide ligand from 50 to $500 \mu \mathrm{g}$.

Glacial acetic acid $(0.1 \mathrm{~mL})$ was added to a vial containing $1.0 \mathrm{mg}$ of $\mathrm{SnCl}_{2} \cdot 2 \mathrm{H}_{2} \mathrm{O}, 28.0 \mathrm{mg}$ of sodium oxalate, $1.5 \mathrm{mg}$ of MDTCZ (or alternatively, BDTCZ) followed by freshly generatoreluted $\mathrm{Na}\left[{ }^{188} \mathrm{ReO}_{4}\right](1.5 \mathrm{~mL}, \sim 300 \mathrm{MBq})$. The mixture was gently warmed up to $50{ }^{\circ} \mathrm{C}$ to ensure dissolution of the reagents and then kept at room temperature for $30 \mathrm{~min}$. To the resulting solution, Cys-Cys-SP $(0.5-0.05 \mathrm{mg}$ dissolved in $0.5 \mathrm{~mL}$ of saline) and 0 . $5 \mathrm{mg}$ of PCN (dissolved in $0.5 \mathrm{~mL}$ of saline containing $2.0 \mathrm{mg}$ of $\gamma$ hydroxypropylcyclodextrin) were simultaneously added. The mixture was heated at $100{ }^{\circ} \mathrm{C}$ for $1 \mathrm{~h}$. The radiochemical yield, as determined by HPLC chromatography, ranged from 86 to $92 \%$ by increasing the concentration of the peptide ligand from 50 to $500 \mu \mathrm{g}$.

\subsection{Chromatography}

Reversed-phase high performance liquid chromatography (RPHPLC) was employed to determine radiochemical yields of radiolabelled compounds using a Beckman System Gold instrument equipped with a programmable solvent model 126 , a sample injection valve 210A, a scanning detector Module 166, and a radioisotope detector Model 170. Analyses were carried out using a reversedphase Agilent precolumn Zorbax 300SB-C18 $(4.6 \times 12.5 \mathrm{~mm})$ and a reversed-phase Agilent column Zorbax 300SB-C18 $(4.6 \times 250 \mathrm{~mm})$ at the flow rate of $1.0 \mathrm{~mL} / \mathrm{min}$. Elution was performed using a combination of solvent $\mathrm{A}\left(0.1 \%\right.$ TFA in water) and solvent $\mathrm{B}\left(0.1 \%\right.$ TFA in $\left.\mathrm{CH}_{3} \mathrm{CN}\right)$ as mobile phase and the following gradient: $0-30 \mathrm{~min}, \% \mathrm{~B}=0-100$; $30-32 \mathrm{~min}, \% \mathrm{~B}=100 ; 32-34 \mathrm{~min}, \% \mathrm{~B}=100-0$. Two main HPLC peaks were observed for both Tc-99m and Re-188 peptide conjugates corresponding to the formation of a syn/anti isomeric pair (see below). Radiochemical yield for all products was expressed as the sum of the \% of peak areas ( $a$ and $b$ ) for the two isomers. Retention times (min) were $R_{\mathrm{Tc}}=15.2(\mathrm{a}), 15.8(\mathrm{~b})$ and $R_{\mathrm{Re}}=15.9(\mathrm{a}), 16.5(\mathrm{~b})$ for Tc-99m and Re188 radioconjugates, respectively.

For in vitro and in vivo studies, the radiocompounds were further purified using the following procedure. The reaction mixture was diluted with $8.0 \mathrm{~mL}$ of water and loaded onto a C18 Sep-Pak cartridge (Waters, Milford, MA) previously activated with ethanol (95\%, $5.0 \mathrm{~mL}$ ) and water $(5.0 \mathrm{~mL})$. The cartridge was rinsed with water $(20.0 \mathrm{~mL})$ and ethanol $(60 \%, 3.0 \mathrm{~mL})$. Finally, the radiocompound was recovered by repeated elution with ethanol $(0.4 \mathrm{~mL}$ followed by $3 \times 1.0 \mathrm{~mL})$. The first fraction was not utilized for biological studies. The remaining fractions were combined, and final radiochemical purity (RCP) checked by HPLC (approximately, 100\%). After slow evaporation of the solvent by flushing a nitrogen stream, isotonic saline was then added to redissolve the radioconjugate.

\subsection{Stability}

The in vitro stability of ${ }^{188} \mathrm{Re}$ and ${ }^{99 \mathrm{~m}} \mathrm{Tc}$ complexes was evaluated by monitoring radiochemical purity (RCP) at different time points $\left(15,30,60,120\right.$ min for ${ }^{99 m}$ Tc complexes and $1,3,24 \mathrm{~h}$ for ${ }^{188} \mathrm{Re}$ complexes). After preparation, the selected radioactive 
compound was purified as described in the previous paragraph. Then, $100 \mu \mathrm{L}$ of the resulting eluate were incubated at $37^{\circ} \mathrm{C}$ with $900 \mu \mathrm{L}$ of saline or PBS. Experiments were conducted in triplicate. Radiochemical purity (RCP) was measured by HPLC chromatography. No significant variation of RCP was observed for both Tc-99m and $\mathrm{Re}-188$ radioconjugates.

\subsection{Cysteine and glutathione (GSH) challenge}

PBS $\left(250 \mu \mathrm{L}, 0.2 \mathrm{~mol} / \mathrm{dm}^{3}, \mathrm{pH}=7.4\right)$, water $(150 \mu \mathrm{L})$, a freshly prepared aqueous solution of L-cysteine or GSH $\left(10.0 \mathrm{mmol} / \mathrm{dm}^{3}\right.$, $50 \mu \mathrm{L}$ ), and a volume of the appropriate HPLC-purified complex $(100 \mu \mathrm{L})$ were placed in a test tube and incubated in a water bath in triplicate at $37^{\circ} \mathrm{C}$. A blank experiment was carried out using an equal volume of saline. Experiments were conducted in triplicate. Aliquots of the resulting solutions were withdrawn at 15, 30, 60, 120 , and $360 \mathrm{~min}$, and analyzed by HPLC. Both Tc-99m and Re-188 radioconjugates were found to be inert towards transchelation by cysteine and GSH.

\subsection{Stability in mouse, rat and human serum}

Stability of Tc-99m and Re-188 radioconjugates was assessed in mouse, rat and human serum using the following procedure. Freshly prepared serum $(225.0 \mu \mathrm{L})$ and the appropriate C18 Sep-Pak purified radioconjugate $(25.0 \mu \mathrm{L})$ were placed in a polypropylene tube and incubated in a water bath, in triplicate at $37^{\circ} \mathrm{C}$. Aliquots of the resulting solutions were withdrawn at 15, 30, 60 and 120 min after incubation, and analysed by HPLC chromatography.

\section{Biological studies}

\subsection{In-vitro cellular studies}

Cellular experiments with SP derivatives have been conducted following methods described previously (Rangger et al., 2013). U-87MG cells (CLS Cell Lines Service, Eppelheim, Germany) were removed from the original medium using a procedure suggested by the supplier and subcultured in Erlenmeyer tissue culture flasks (Dispomeyer, VWR International PBI, Milan, Italy) using Dulbecco's modified Eagle medium (DMEM) supplemented with 10\% volume/ volume $(\mathrm{v} / \mathrm{v})$ heat-inactivated fetal bovine serum, $1 \% \mathrm{v} / \mathrm{v}$ penicillin/ streptomycin/L-glutamine solution, $1 \% \mathrm{v} / \mathrm{v}$ sodium pyruvate solution, and $1 \% \mathrm{v} / \mathrm{v}$ non-essential amino acid solution (NEAA). Cell lines were grown to confluence at $37{ }^{\circ} \mathrm{C}$ in a humidified atmosphere of $95 \%$ air $/ 5 \%$ carbon dioxide and split every $48 \mathrm{~h}$. Similarly, mouse fibroblast cells (L-929) (CLS Cell Lines Service, Eppelheim, Germany) were removed from the original medium and subcultured in DMEM supplemented with $10 \% \mathrm{v} / \mathrm{v}$ heat-inactivated fetal bovine serum, $1 \% \mathrm{v} / \mathrm{v}$ L-glutamine, $1 \% \mathrm{v} / \mathrm{v}$ NEAA, and $1 \% \mathrm{v} / \mathrm{v}$ antibiotic/antimycotic in tissue culture flasks. The cells were grown to confluence at $37{ }^{\circ} \mathrm{C}$ in a humidified atmosphere of $95 \%$ air $/ 5 \%$ carbon dioxide.

For experimental studies, the cancer cell line (U-87MG) and the mouse fibroblast cell line (L-929) as negative control were grown overnight in a plastic sterile test-tube (Coltube, VWR International PBI, Milan, Italy) until reaching a growth density of about $40-50 \%$. The radioconjugate, purified through a $\mathrm{C} 18$-Sep-Pak cartridge, was diluted 1:250 times (approximately, $2 \times 10^{5} \mathrm{cpm}$ ) using the appropriate cell culture medium and incubated with cells for 15 min at $37^{\circ} \mathrm{C}$. After incubation, the test tube was centrifuged $(3 \mathrm{~min}$, $500 \mathrm{~g}$ ), supernatant was removed and cells were washed twice with phosphate-buffered saline and counted using a gamma counter (Minaxi 5550, Packard). Experiments were conducted in triplicate. Cell uptake was calculated with respect to an aliquot of the initial activity representing total activity. Uptake values expressed as \% of the total activity were $58.49 \pm 0.35$ (Tc-99m) and $61.37 \pm 1.02$ (Re-188) for U-87MG cells and $2.95 \pm 1.17$ (Tc$99 \mathrm{~m})$ and $1.96 \pm 0.95$ (Re-188) for L-929 cells.

\subsection{Micro-SPECT/CT imaging studies}

Animal experiments were carried out incompliance with the relevant national laws relating to the conduct of animal experimentation and EU Directive 2010/63/EU. SPECT studies have been performed using a YAP(S)PET scanner (Del Guerra et al., 2006). A mouse ( $\sim 25 \mathrm{~g}$ ) was anesthetized with an intramuscular injection of a mixture of ketamine $(80 \mathrm{mg} / \mathrm{kg})$ and xilazine $(19 \mathrm{mg} / \mathrm{kg})$ and then injected with $75 \mathrm{MBq}(2 \mathrm{mCi})$ of the ${ }^{99 \mathrm{~m}} \mathrm{Tc}$-labeled peptide to determine its wholebody distribution. The mouse was scanned the first time for $60 \mathrm{~min}$ starting 20 min after injection. The SPECT acquisition consisted of 3 bed positions $3 \mathrm{~cm}$ apart, $20 \mathrm{~min}$ for each position, 128 views over $360^{\circ}$. The used energy window is $140-250 \mathrm{keV}$ and the images were reconstructed by using the iterative EM-ML algorithm including the collimator response.

Radiographic images have been acquired using the digital X-ray imaging system integrated into the YAP(S)PET scanner (Di Domenico et al., 2007). Acquisition parameters for X-ray projections were: X-ray tube voltage $=35 \mathrm{kV}$, anode current $=1 \mathrm{~mA}$ exposure $=1 \mathrm{~s}, 8$ views over $360^{\circ}$, magnification factor $=1.2$. Subtraction of dark noise contribution and flat field corrections were accomplished to obtain final images.

Planar images were also collected in a second mouse, pretreated as described above after $180 \mathrm{~min}$ from injection of $92 \mathrm{MBq}$ (2.5 $\mathrm{mCi}$ ), using the same scanner (image not reported here). At the conclusion of the image acquisition, both animals were sacrificed by cervical dislocation and thymus glands were excised, washed with saline, weighed and counted for radioactivity. Observed values were 0.0132 and 0.00938 expressed as percent of injected activity per gram (\% $\left.\mathrm{IA}^{-1}\right)$, respectively.

\section{Results and discussion}

\subsection{Preparation of peptide radioconjugates}

Radiolabelling of the peptide Cys-Cys-SP with Tc-99m was carried out through a well-established two-step method involving the first formation of the $\left[{ }^{99 m} \mathrm{Tc} \equiv \mathrm{N}\right]^{2+}$ core followed by addition of the relevant coordinating ligands. The $\left[{ }^{99 \mathrm{~m}} \mathrm{Tc} \equiv \mathrm{N}\right]^{2+}$ group was prepared by the usual reaction of $\left[{ }^{99 \mathrm{~m}} \mathrm{Tc}\right]\left[\mathrm{TcO}_{4}\right]^{-}$with a reagent capable to donate nitrido nitrogen atoms $\left(\mathrm{N}^{-3}\right)$ in the presence of a reducing agent. Succinic dihydrazide $(\mathrm{SDH})$ and $\mathrm{SnCl}_{2}$ are standard reagents commonly employed for this purpose (Boschi et al., 2005). Simultaneous addition of both Cys-Cys-SP and tris (2-cyanoethyl)phosphine (PCN) to the preformed $\left[{ }^{99 m} \mathrm{Tc} \equiv \mathrm{N}\right]^{2+}$ group afforded the final radioconjugate $\left[{ }^{99 \mathrm{~m}} \mathrm{Tc}\right][\mathrm{Tc}(\mathrm{N})(\mathrm{Cys}-\mathrm{Cys}-\mathrm{SP})$ $(\mathrm{PCN})]$. This compound is neutral as a result of the coordination of the two terminal cysteine residues as a dianionic, tridentate chelating system through two deprotonated thiol sulfur atoms and one neutral, protonated, amino nitrogen atom. Residual protonation of this nitrogen atom is responsible of the existence of two isomeric forms of the resulting radioconjugate, which originate from the reciprocal syn or anti (across or opposite) position of the amino hydrogen with respect to the $\mathrm{Tc} \equiv \mathrm{N}$ triple bond (Boschi et al., 2012). Despite this tiny structural difference, the two isomers were well separated by HPLC as evidenced by the presence of two adjacent peaks in the chromatographic profile of the final Tc-99m compound (Fig. 3).

The preparation of the corresponding Re-188 analogue was more demanding as expected from the differences in redox 


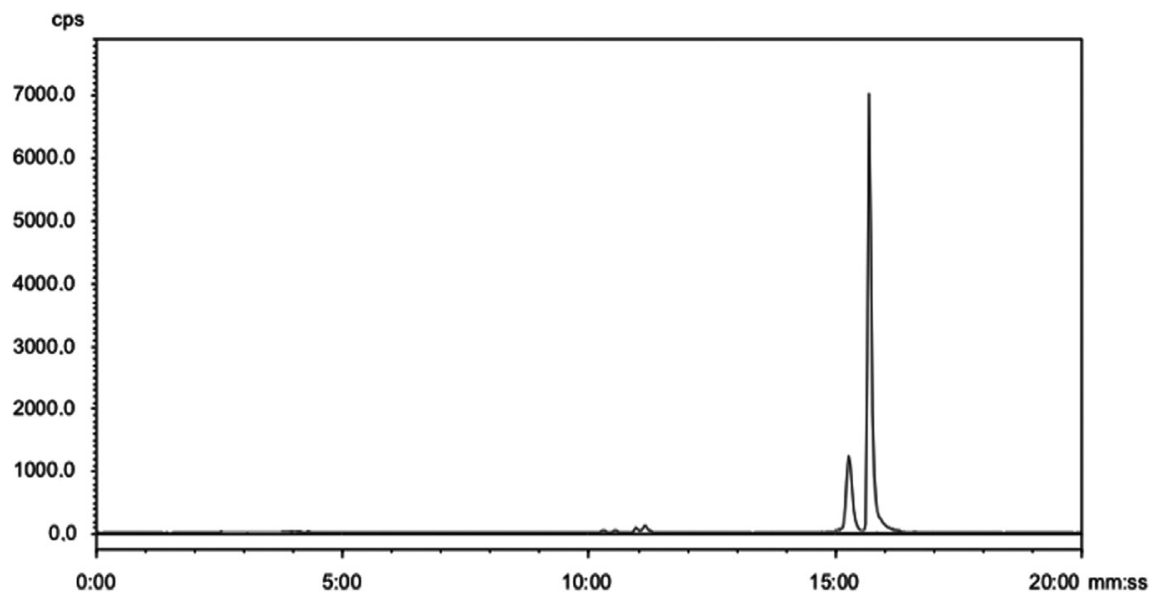

Fig. 3. Representative HPLC chromatogram of the compound $\left[{ }^{99 m} \mathrm{Tc}\right][\mathrm{Tc}(\mathrm{N})($ Cys-Cys-SP)(PCN)].

potentials between technetium and rhenium. In particular, the reduction of $\left[{ }^{188} \mathrm{Re}\right]\left[{ }^{188} \mathrm{ReO}_{4}\right]^{-}$needed an additional boost that was imparted by the combined action of $\mathrm{SnCl}_{2}$ and oxalate ions (Bolzati et al., 2000). A crucial role was played by the donor of $\mathrm{N}^{-3}$ ions, which has to be carefully selected since SDH was found not to be a suitable reagent for producing the $\left[{ }^{188} \mathrm{Re} \equiv \mathrm{N}\right]^{2+}$ core. It turned out that $N$-methyl $S$-methyl dithiocarbazate [DTCZ $=\mathrm{H}_{2} \mathrm{NNC}(=\mathrm{S}) \mathrm{SCH}_{3}$ ], a compound previously employed as nitrido donor reagent, was more effective in generating the $\left[{ }^{188} \mathrm{Re} \equiv \mathrm{N}\right]^{2+}$ group (Boschi et al., 2003). However, DTCZ is also a good coordinating ligand for the same group and this thereby carries out the need for using a large excess of the final ligands for its removal. Evidently, this may constitute a drawback for peptide labeling since usually the concentration of free peptide ligand should be kept as lower as possible to avoid saturation of the target biological receptors. Recently, we demonstrated that by appending sterically encumbering chemical groups to the basic DTCZ moiety significantly impaired its coordination ability while keeping unaltered its donor properties. For this purpose, the derivative PEG-DTCZ was synthesized where a long polyethyleneglycol chain was tethered to the terminal nitrogen atom of DTCZ (Boschi et al., 2010). Though this reagent was highly efficient in affording the $\left[{ }^{188} \mathrm{Re} \equiv \mathrm{N}\right]^{2+}$ core, its preparation is lengthy and cumbersome since it involves many purification steps to achieve the required purity. In this study, we employed the compounds methyl 2-(3,4-dichlorobenzoyl)-1-methylhydrazinecarbodithioate $\left[\mathrm{Cl}_{2} \mathrm{C}_{6} \mathrm{H}_{3} \mathrm{C}(=\mathrm{O}) \mathrm{NH}-\mathrm{N}\left(\mathrm{CH}_{3}\right) \mathrm{SCH}_{3}=\mathrm{BDTCZ}\right]$, or alternatively butyl 2(3,4-dichlorobenzoyl)-1-methylhydrazinecarbodithioate $\left[\mathrm{Cl}_{2} \mathrm{C}_{6} \mathrm{H}_{3} \mathrm{C}\right.$ $(=\mathrm{O}) \mathrm{NH}-\mathrm{N}\left(\mathrm{CH}_{3}\right) \mathrm{SC}_{4} \mathrm{H}_{9}=\mathrm{BDTCZ}$, as simpler derivatives of DTCZ, which proved useful for obtaining the same result. The chemical structures of these products are illustrated in Fig. 4. Using these reagents, satisfactory yields of production of the final $\left[{ }^{188} \mathrm{Re}\right][\mathrm{Re}$ (Cys-Cys-SP)(PCN)] conjugate were obtained. HPLC characterization revealed the same chromatographic pattern corresponding to the presence of syn and anti isomers, thus convincingly supporting the conclusion that the Tc-99m and Re-188 derivatives share a common structural arrangement.

A schematic illustration of the chemical structure of these radiocompounds is reported in Fig. 5.

\subsection{Stability}

Both Tc-99m and Re-188 SP radioconjugates were found to be stable in solutions and in mouse blood serum. However, incubation with rat and human serum showed marked species dependence since a progressive decrease in RCP was measured over time (Fig. 6). Specifically, in rat serum a sharp decrease of RCP below<smiles>CN(C(=O)c1ccc(Cl)c(Cl)c1)C(=S)[S-]</smiles>

MDTCZ<smiles>CCCCC(=S)N(C)NC(=O)c1ccc(Cl)c(Cl)c1</smiles>

BDTCZ

Fig. 4. Drawings of the chemical structures of MDTCZ and BDTCZ.

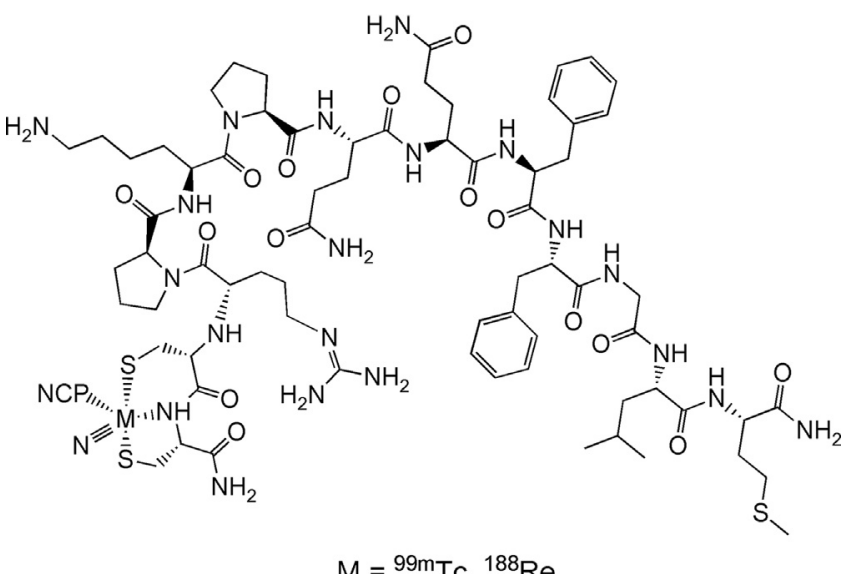

Fig. 5. Drawings of the chemical structures of $[\mathrm{M}(\mathrm{N})(\mathrm{Cys}-\mathrm{Cys}-\mathrm{SP})(\mathrm{PCN})](\mathrm{M}=\mathrm{Tc}-$ 99m, Re-188).

$80 \%$ was observed after 30 min, whereas the same decomposition was detected in human serum after $60 \mathrm{~min}$. At present, it remains unclear whether this in vivo instability resulted from decomposition affecting the metal containing moiety, from oxidation of the methionine residue on the peptide sequence (Bjellaas et al., 2004; Guan et al., 2003) or other degradation processes. The remarkable 


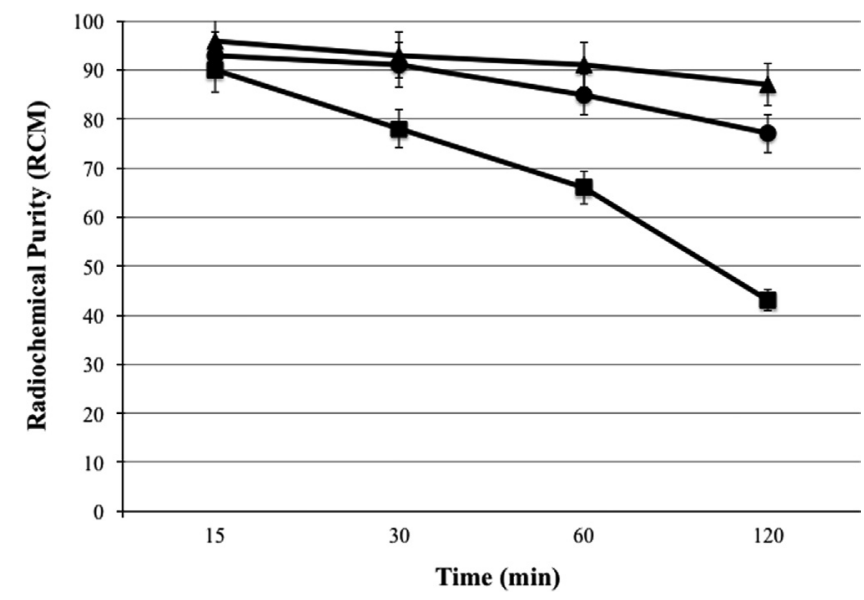

Fig. 6. Time variation of radiochemical purity $(R C P)$ of $\left[{ }^{99 m} \mathrm{Tc}\right][\mathrm{Tc}(\mathrm{N})($ Cys-Cys-SP) $(\mathrm{PCN})]$ after incubation with mouse $(\boldsymbol{\bullet})$, rat $(\bullet)$ and human serum $(\bullet)$.

differences between results obtained in mouse, rat and human serum point to some specific species dependent mechanism for the observed instability rather than to unspecific oxidative decomposition. Besides, the absence of detectable amounts of free pertechnetate and perrhenate supports the view that the chelating system retains its integrity in the biological medium without release of the radiometal. This relative inertness of the metallic moiety has been also evidenced in challenging experiments with cysteine and glutathione. However, further comparative studies are required to clarify the origin of the observed instability, as particularly found in rat serum.

\subsection{Biological characterization}

Though the present work was mostly devoted to investigate the application of a new labeling method to SP as a model peptide, preliminary characterization of the affinity of the resulting radioconjugates for NK1 receptor expressing cells have been carried out. Incubation with either Tc-99m or Re-188 SP radioconjugates resulted in no detectable binding with the negative control cell line L-929. The most pronounced cell surface binding was observed after incubation with U-87 MG cells, which reflects the expression level of NK1 receptors on these cells. Retention of radioactivity was significant with both Tc-99m and Re-188 radioconjugates, thus suggesting a comparable affinity for the same surface membrane receptors.

Whole-body biodistribution studies were carried out with a hybrid SPECT/CT YAP(S)PET small-animal tomograph after administration of the Tc-99m analogue. Images collected at 60 min post injection showed a predominant kidney elimination and uptake in a small region apparently associated with the thymus (Fig. 7) where specific SP binding sites have been previously recognized (Breeman et al., 1996; Van Hagen et al., 2005). This finding was convincingly supported by ex-vivo measurement, which revealed detectable radioactive accumulation in the thymus gland isolated from the same animal employed for imaging studies. Similarly, planar images collected at 180 min after administration of the tracer were consistent with this result as they showed uptake in a large region including the thymus, heart and some delayed liver and intestinal washout. Significant uptake in salivary glands was also observed. Ex-vivo measurements ruled out myocardial accumulation and confirmed uptake by the thymus. In the present work, no further investigation was pursued to determine whether the observed uptake was receptor-mediated or simply unspecific and, thus, more accurate studies are required.

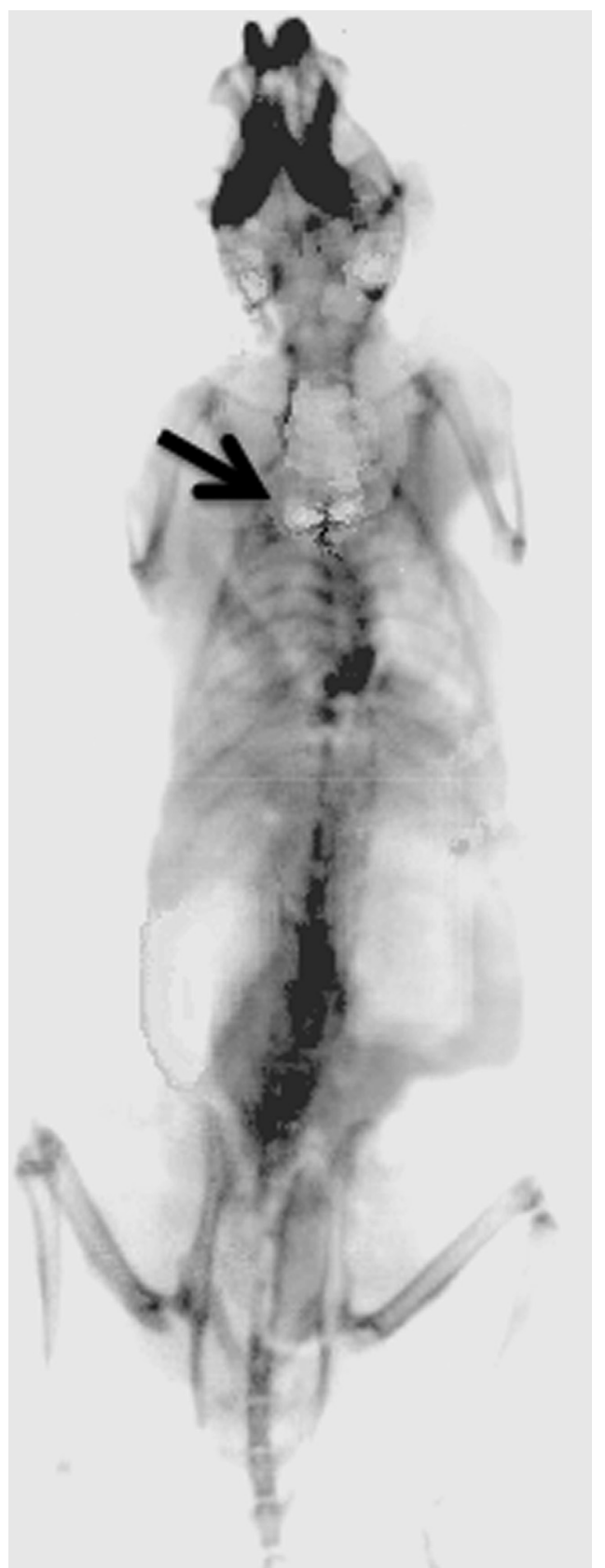

Fig. 7. Hybrid SPECT/CT image of a mouse collected after 60 min from administration of $74 \mathrm{MBq}$ of $\left[{ }^{99 \mathrm{~m}} \mathrm{Tc}\right][\mathrm{Tc}(\mathrm{N})($ Cys-Cys-SP)(PCN)].

\section{Conclusions}

New Tc-99m and Re-188 radioconjugates of SP have been successfully prepared by applying a novel labeling strategy based on the combined reaction of tridentate $\pi$-donor and monodentate $\pi$-acceptor ligands with the $[\mathrm{M} \equiv \mathrm{N}]^{2+}\left(\mathrm{M}={ }^{99 \mathrm{~m}} \mathrm{Tc},{ }^{188} \mathrm{Re}\right)$ metallic functional group. A version of this approach, which proved to be particularly convenient for labeling short peptide sequences was employed here. This involves designing of the appropriate tridentate chelating system through a simple combination of a pair of natural aminoacids. The resulting Tc-99m and Re-188 radiopharmaceuticals were demonstrated to possess the same molecular geometry and, as a consequence, their observed biological behavior was superimposable, thus providing a further example of a true diagnostic and therapeutic (theranostic) Tc- $99 \mathrm{~m} / \mathrm{Re}-188$ matching pair. 


\section{Acknowledgments}

K. S. gratefully acknowledges support from the International Atomic Energy Agency, Vienna, Austria, through grant IAEA TC-RER/6/017.

\section{References}

Ansquer, C., Kraeber-Bodéré, F., Chatal, J.F., 2009. Current status and perspectives in peptide receptor radiation therapy. Curr. Pharm. Des 15, 2453-2462.

Bjellaas, T., Holm, A., Molander, P., Tørnes, J.A., Greibrokk, T., Lundanes, E., 2004. Trace determination of peptides in water samples using packed capillary liquid chromatography with UV and MS detection and characterization of peptide oxidation products by MS. Anal. Bioanal. Chem. 378, 1021-1030.

Benoiton, N.L., 2005. Chemistry of Peptide Synthesis. Taylor\& Francis, London, pp. $125-154$.

Bhattacharyya, S., Dixit, M., 2011. Metallic radionuclides in the development of diagnostic and therapeutic radiopharmaceuticals. Dalton Trans. 40, 6112-6128.

Bolzati, C., Boschi, A., Uccelli, L., Duatti, A., Franceschini, R., Piffanelli, A., 2000. An alternative approach to the preparation of ${ }^{188} \mathrm{Re}$ radiopharmaceuticals from generator-produced $\left[{ }^{188} \mathrm{ReO}_{4}\right]^{-}$: efficient synthesis of ${ }^{188} \mathrm{Re}(\mathrm{V})$-meso-2,3dimercaptosuccinic acid. Nucl. Med. Biol. 27, 309-314.

Boschi, A., Cazzola, E., Uccelli, L., Pasquali, M., Ferretti, V., Bertolasi, V., Duatti, A., 2012. Rhenium(V) and technetium(V) nitrido complexes with mixed tridentate $\pi$-donor and monodentate $\pi$-acceptor ligands. Inorg. Chem. 51, 3130-3137.

Boschi, A., Uccelli, L., Pasquali, M., Pasqualini, R., Guerrini, R., Duatti, A., 2013. Mixed tridentate $\pi$-donor and monodentate $\pi$-acceptor ligands as chelating systems for rhenium-188 and technetium-99m nitrido radiopharmaceuticals. Curr. Radiopharm 6, 137-145.

Boschi, A., Duatti, A., Uccelli, L., 2005. Development of technetium-99m and rhenium-188 radiopharmaceuticals containing a terminal metal-nitrido multiple bond for diagnosis and therapy. Top. Curr. Chem. (Contrast Agents III) 252 $85-115$.

Boschi, A., Massi, A., Uccelli, L., Pasquali, M., Duatti, A., 2010. PEGylated N-methyl-Smethyl dithiocarbazate as a new reagent for the high-yield preparation of nitrido Tc-99m and Re-188 radiopharmaceuticals. Nucl. Med. Biol. 37, 927-934.

Boschi, A., Bolzati, C., Uccelli, L., Duatti, A., 2003. High-yield synthesis of the terminal ${ }^{188} \mathrm{Re} \equiv \mathrm{N}$ multiple bond from generator-produced $\left[{ }^{188} \mathrm{ReO}_{4}\right]$. Nucl. Med. Biol. 30, 381-387.

Breeman, W.A., Van Hagen, M.P., Visser-Wisselaar, H.A., van der Pluijm, M.E., Koper, J.W., Setyono-Han, B., Bakker, W.H., Kwekkeboom, D.J., Hazenberg, M.P.
Lamberts, E.P., Visser, T.J., Krenning, E.P., 1996. in vitro and in vivo studies of substance $\mathrm{P}$ receptor expression in rats with the new analog [indium-111DTPA-Arg1]substance P. J. Nucl. Med. 37, 108-117.

Del Guerra, A., Bartoli, A., Belcari, N, Herbert, N., Motta, D., Vaiano, A., Di Domenico, A., Sabba, G., Moretti, N., Zavattini, E., Lazzarotti, G., Sensi, M., Larobina, M., L. 2006. Performance evaluation of the fully engineered YAP-(S)PET scanner for small animal imaging. IEEE Trans. Nucl. Sci. 53, 1078-1083.

Di Domenico, G. Cesca, N., Zavattini, G., Auricchio, N., Gambaccini, M., 2007. CT with a CMOS flat panel detector integrated on the YAP(S)PET scanner for in vivo small animal imaging. Nucl. Instrum. Methods Phys. Res., Sect. A 571, 110-113.

Duatti, A., 2011. Fundamentals of technetium and rhenium chemistry. In: Theobald, T. (Ed.), Sampson's Textbook of Radiopharmacy, fouth ed. Pharmaceutical Press, London, pp. 97-119.

Ferro-Flores, G., Arteaga de Murphy, C., 2008. Pharmacokinetics and dosimetry of ${ }^{188}$ Re-pharmaceuticals. Adv. Drug Delivery Rev. 60, 1389-1401.

Guan, Z., Yates, N.A., Bakhtiar, R., 2003. Detection and characterization of methionine oxidation in peptides by collision-induced dissociation and electron capture dissociation. J. Am. Soc. Mass. Spectrom 14, 605-613.

Guhlke, S., Beets, A.L., Oetjen, K., Mirzadeh, S., Biersack, H.J., Knapp Jr., F.F., 2000. Simple new method for effective concentration of ${ }^{188} \mathrm{Re}$ solutions from alumina- based ${ }^{188} \mathrm{~W}-{ }^{188}$ Re generator. J. Nucl. Med. 41, 1271-1278.

Kelkar, S.S, Reineke, T.M., 2011. Theranostics: combining imaging and therapy. Bioconjug. Chem. 22, 1879-1903.

Park, J.A., Kim, J.Y., 2013. Recent advances in radiopharmaceutical application of matched-pair radiometals. Curr. Top. Med. Chem. 13, 458-469.

Pillai, M.R, Dash, A., Knapp Jr., F.F., 2012. Rhenium-188: availability from the ${ }^{188} \mathrm{~W} /{ }^{188} \mathrm{Re}$ generator and status of current applications. Curr. Radiopharm 5, $228-243$.

Price, E.W., Orvig, C., 2014. Matching chelators to radiometals for radiopharmaceuticals. Chem. Soc. Rev. 43, 260-290.

Rangger, C., Helbok, A., Sosabowski, J., Kremser, C., Koehler, G., Prassl, R., Fritz Andreae, F., Virgolini, I.J., von Guggenberg, E., Decristoforo, C., 2013. Tumor targeting and imaging with dual-peptide conjugated multifunctional liposomal nanoparticles. Int. J. Nanomed. 8, 4659-4671.

Solé, N.A., Barany, G., 1992. Optimization of solid-phase synthesis of [Ala8]dynorphin. J. Org. Chem. 57, 5399-5403.

Szczesio, M., Olczak, A., Gobis, K., Foksb, H., Główka, M.L., 2012. Acta Crystallogr., Sect. C: Cryst. Struct. Commun. 68, o373-0376.

Van Hagen, P.M., Breeman, W.A.P., Reubi, J.C., Postema, P.T.E., van den AnkerLugtenburg, P.J., Kwekkeboom, D.J., Laissue, J., Waser, B., Lamberts, S.W.J., Visser, T.J., Kreening, E.P., 2005. Visualization of the thymus by substance P receptor scintigraphy in man. Eur. J. Nucl. Med. 23, 1508-1513. 